\title{
Understanding the Mechanism of
}

Decomposition Reactions of Neat and Superplasticized ordinary Portland Cement Pastes Using Thermal

\section{Analysis}

ELSHAFIE A. M. GAD - Egyptian Petroleum Research Institute - eamgad@gmail.com

AmR Osman HABIB - Chemistry Dept. Faculty of Engineering, Ain Shams University

- amrhabib2004@yahoo.com

Mahmoud M. MOUSA - Faculty of Science, Benha University - mousa_chem@yahoo.com

Érkezett: 2017. 10. 25. - Received: nn. hh. 2017. - https://doi.org/10.14382/epitoanyag-jsbcm.2017.18

\begin{abstract}
The effect of polycarboxylate superplasticizer on thermal stability and the kinetic thermal decomposition of OPC without and with 1.0 and 1.5\% wt\% plasticizer has been studied at temperature range of $30-1000{ }^{\circ} \mathrm{C}$. The study was done by means of thermogravimetry (TG) technique under non-isothermal condition at a heating rate of $10 \mathrm{~K} / \mathrm{min}$. The results showed that the decomposition occurs for the superplasticized and neat OPC paste in three steps. The neat OPC was found to decompose at higher temperatures than those for the superplasticized paste. The kinetic parameters for each one of the decomposition steps were calculated through four calculation methods and the kinetic mechanisms were determined from the thermal data analysis using 35 solid state reaction models. The results showed that the mechanisms of decomposition steps depend on the percentage of the superplasticizer added to the paste. The thermodynamic parameters $\Delta \mathrm{S}^{\#}, \Delta \mathrm{H}^{\#}$ and $\Delta \mathrm{G}^{\#}$ were also computed and discussed.

Keywords: Hydration kinetics; Ordinary Portland cement OPC; Thermogravimetrical Analyses TGA. Kulcsszavak: Hidratációkinetika; Tiszta Portlandcement ; Termogravimetriai analízis
\end{abstract}

\section{Introduction}

Calcium silicate hydrates $(\mathrm{CSH})$ and calcium hydroxide $(\mathrm{CH})$ which are the main hydration phases accounted for the properties of Portland cement paste. The dehydration of Portland cement paste causes a deterioration effect on the concrete strength. Thermal analysis tools can be used to identify each of the product compositions and their amounts due to thermal effects on cement composites. Several investigators studied thermal analysis to recognize the products due to hydration of different cement composites [1,2,3]. Zelic et al. [4] investigated thermal decomposition kinetics of the calcium hydroxidePortlandite formed into hydrated ordinary Portland cement (OPC) paste with use of non-isothermal thermogravimetric data. Sha et al. [5] reported that the three major endothermic peaks in the DSC curves are due to loss of water from calcium silicate hydrate, dehydroxyaltion of calcium hydroxide, and decarbonation of calcium carbonate contribute respectively. Pane et al. [6] investigated hydration of OPC pastes containing three types of mineral additive; fly ash, ground-granulated slag, and silica fume using DTA/TGA and isothermal calorimetry It was shown that the chemically bound water obtained using DTA/TGA was proportional to heat of hydration and could be used as a measure of hydration. Agarwal et al. [7] studied the hydration behavior of different cements at different time intervals in the presence of superplasticizers using DTA technique. It was observed that OPC has shown retardation either blended with naphthalene-based superplasticizers or with blended polymer-based superplasticizer. However,
Prof. Dr. Elshafie A. GAD Professor of Petrochemicals. My interests are surfactants applications, QSPR, Computational chemistry and recently Solid state Kinetics.

Dr. Amr Osman HABIB received his M.Sc and Ph.D from Ain Shams University, Cairo, Egypt. He is currently a lecturer at Faculty of Engineering, Ain Shams University. He is a member of Technology of Building Materials and Pore Structure of Solids Unit, (R \& D Unit), Faculty of Science, Ain Shams University, and member of The Engineering Consultants Centre, Faculty of Engineering, Ain Shams University.

Prof. Dr. Emer. Mahmoud M. MOUSA Faculty of Science, Benha University, his interests are treatment of industrial solid wastes, renal function Studies, Iminodiacetic Acid Analog Nanomaterials application and solid state kinetics.

Portland Slag Cement has been found to be compatible with all the superplasticizers. Ye et al. [8] reported on the properties of Self-compacting when it is exposed to elevated temperatures. Fire test has shown differences between high performance concrete and traditional concrete at elevated temperature. These differences are largely depending on the microstructural properties of concrete matrix. Kong et al. [ 9] studied the effect of elevated temperature on geopolymer paste, mortar and concrete made using fly ash as a precursor. It was found that strength loss in geopolymer concrete at elevated temperatures is attributed to the thermal mismatch between the geopolymer matrix and the aggregates. Heikal et al. [10] studied the effect of substitution of nano-silica on the behavior of composite cement pastes including OPC and blastfurnace slag exposed to elevated temperature up to $1000^{\circ} \mathrm{C}$. DTA and TGA were carried out on cement pastes partially replaced with Neem seed husk ash [11]. The results showed that the calcium hydroxide contents increases with increase in Neem seed husk ash replacements. Klimesch and Ray [12] presented a method for consistent DTA/TGA evaluation using computer software for data analyses. DTA/TGA was used to study the effect of ground quartz addition to cement. AlarconRuiz et al. [13] used thermal analysis techniques to study the effect of temperature in the mineralogical composition of cement hydration products. Such techniques can be used to determine fire conditions and the consequent deterioration expected in the cement paste. Bhatty and Reid [14] produces high-strength Type 1 cement. The product from raw taconite 
Oxide $\quad \mathrm{SiO}_{2} \quad \mathrm{Al}_{2} \mathrm{O}_{3} \quad \mathrm{Fe}_{2} \mathrm{O}_{3} \quad \mathrm{CaO} \quad \mathrm{MgO} \quad \mathrm{SO}_{3} \quad \mathrm{Na}$-Oxide $\mathrm{K}$ - Oxide Lime Saturation Factor Undissolved solids Loss on Ignition

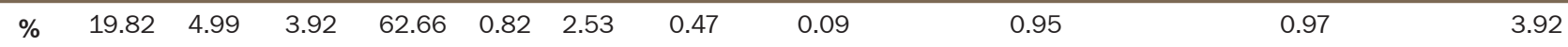

Table 1 Chemical analysis of ordinary Portland cement

1. táblázat Portlandcement kémiai összetétele

and copper-nickel tailings of Minnesota is the subjected to hydration studies by using thermal methods such as TGA and DTA. Hydration is measured in terms of hydration product formation and the amount of bound water and free calcium hydroxide incorporated in them.

Reactions that occur with an increase of temperature in cement paste and concrete can be summarized as: evaporable water and a part of the bound water escapes at $30-102^{\circ} \mathrm{C}[4]$. The decomposition of gypsum [15] and ettringite [16] takes place at $110-170^{\circ} \mathrm{C}$, The decomposition of the C-S-H and carboaluminate hydrates undergoes at $180-300^{\circ} \mathrm{C}$ [17]. Dehydroxylation of the portlandite [18] occurs at $450-550^{\circ} \mathrm{C}$. Decarbonation of calcium carbonate happens at $700-900^{\circ} \mathrm{C}[13]$.

However, the dehydration kinetics of Portland cement paste is too complex and can not be described by a single Arrhenius equation. In the present work, we studied the thermal dehydration and decomposition kinetics of OPC hardened pastes containing polycarboxylate admixtures using TGA at a heating rate of $10 \mathrm{~K} / \mathrm{min}$ for two samples containing admixtures besides, control sample. Four calculation procedures based on TG curves as well as 35 mechanism functions were applied on the thermal data.

\section{Materials and experimental technique}

Cement: A freshly produced sample of a commercial ordinary Portland cement supplied from Suez Cement Company with the chemical composition listed in Table 1, was used in this study.

The specific surface area as determined by the Blaine airpermeability method was found to be $3400 \mathrm{~cm}^{2} / \mathrm{gm}$. The potential phase composition as estimated using Bogue's calculation [19] was found to be $\mathrm{C}_{3} \mathrm{~S}, 58.04 ; \beta-\mathrm{C}_{2} \mathrm{~S}, 13.11 ; \mathrm{C}_{3} \mathrm{~A}$, 6.59 and $\mathrm{C}_{4} \mathrm{AF}, 11.91$, respectively.

\section{Preparation of OPC pastes}

The percentages of admixtures (1.0 \& $1.5 \mathrm{wt} \%)$ were dissolved in water of mixing. Various cement pastes were prepared by mixing OPC with water using standard water of consistency for each paste. The control cement pastes and the superplasticized samples with 1.0 and $1.5 \mathrm{wt} \%$ were hydrated for 28 days.

The standard water of consistency and percentage of water reduction were listed in Table 2.

\begin{tabular}{lcc} 
Paste & W/C ratio & Water reduction \% \\
\hline Neat OPC & 0.245 & $0 \%$ \\
\hline OPC+1\%1\% & 0.1712 & $30 \%$ \\
\hline OPC+1.5\% & 0.16 & $34.69 \%$
\end{tabular}

Table 2. The standard water of consistency and percentage of water reduction for the control and superplasticized cement pastes

2. táblázat Szabványos konzisztencia vízigénye és a viztartalom csökkenés mértéke folyósitószer hatására

\section{Thermal analysis}

The thermal decomposition of the different hardened cement pastes was studied by thermal gravimetric analysis (TGA) technique using Simultaneous TGA/DSC MODEL SDTQ 600 Thermal Analyzer (USA). Some grains were extracted from the inner core of the hardened cement pastes. These grains were crushed and ground until a grain size of $80 \mu \mathrm{m}$ was obtained. The temperature of the furnace was programmed to rise as a constant heating rate of $10^{\circ} \mathrm{C} / \mathrm{min}$ up to $1000{ }^{\circ} \mathrm{C}$

\section{Background on non-isothermal decomposition kinetics}

Kinetic process calculations result in three parameters; $i$. e., Ea is the activation energy, $\mathrm{A}$ is the pre-exponential factor, $f(\alpha)$ represents the mathematical form of the mechanism to be assumed for the process, and $\alpha$ is the conversion degree. The rate determining mechanism model may take various forms based nucleation and nucleus growth, phase boundary reaction, diffusion and chemical reaction [20].

The reaction rate equation for non-isothermal decomposition kinetics [20] can be written as follows:

$$
\frac{d \alpha}{d t}=k(T) f(\alpha)
$$

Where $k$ is the rate constant and the conversion factor $\alpha$ is defined as:

$$
\alpha=\frac{m_{i-} m_{t}}{m_{i}-m_{\infty}}
$$

Where $m_{i}$ is the initial mass of the sample, $m_{t}$ is the mass of the sample at time $t$, and $m_{\infty}$ is the residual mass of the sample at the end of the reaction.

Integration of Eq. (1) gives the integral rate law:

$$
g(\alpha)=k t
$$

The rate constant $\mathrm{k}$ is generally given by the Arrhenius equation:

$$
k=A \exp \left(\frac{-E_{a}}{R T}\right)
$$

Where $\mathrm{E}_{\mathrm{a}}$ is the activation energy, $\mathrm{R}$ is the gas constant, and $\mathrm{T}$ is the absolute temperature. The combination of Eqs. (1) and (4) gives the following relationship:

$$
\frac{d \alpha}{d t}=A \exp \left(\frac{-E_{a}}{R T}\right) f(\alpha)
$$

For a dynamic TG process, introducing the heating rate, $\beta=$ dT/dt, into Eq. (5), gives Eq. (6):

$$
\frac{d \alpha}{d t}=\left(\frac{A}{\beta}\right) \exp \left(\frac{-E_{a}}{R T}\right) f(\alpha)
$$


1. Chemical process or mechanism non-invoking equations

\begin{tabular}{cclcc}
$\mathbf{1}$ & $F_{1 / 3}$ & One-third order & $1-(1-a)^{2 / 3}$ & $(3 / 2)(1-a)^{1 / 3}$ \\
\hline $\mathbf{2}$ & $F_{3 / 4}$ & Three-quarters order & $1-(1-a)^{1 / 4}$ & $4(1-a)^{3 / 4}$ \\
\hline $\mathbf{3}$ & $F_{3 / 2}$ & One and a half order & $(1-a)^{-1 / 2}-1$ & $2(1-a)^{3 / 2}$ \\
\hline $\mathbf{4}$ & $F_{2}$ & Second order & $(1-a)^{-1}-1$ & $(1-a)^{2}$ \\
\hline $\mathbf{5}$ & $F_{3}$ & Third order & $(1-a)^{-2}-1$ & $(1 / 2)(1-a)^{3}$
\end{tabular}

Chemical reaction

Chemical reaction

Chemical reaction

Chemical reaction

2. Acceleratory rate equations

\begin{tabular}{cclccc}
$\mathbf{6}$ & $\mathrm{P}_{3 / 2}$ & Mampel power law & $a^{3 / 2}$ & $(2 / 3) a^{-1 / 2}$ & Nucleation \\
\hline $\mathbf{7}$ & $\mathrm{P}_{1 / 2}$ & Mampel power law & $\mathrm{a}^{1 / 2}$ & $2 \mathrm{a}^{1 / 2}$ & Nucleation \\
\hline $\mathbf{8}$ & $\mathrm{P}_{1 / 3}$ & Mampel power law & $\mathrm{a}^{1 / 3}$ & $3 \mathrm{a}^{2 / 3}$ & Nucleation \\
\hline $\mathbf{9}$ & $\mathrm{P}_{1 / 4}$ & Mampel power law & $\mathrm{a}^{1 / 4}$ & $4 \mathrm{a}^{3 / 4}$ & Nucleation \\
\hline $\mathbf{1 0}$ & $\mathrm{E}_{1}$ & Exponential law & $\mathrm{Ln} a$ & $\mathrm{~A}$ & Nucleation
\end{tabular}

\section{Sigmoidal rate equations or random nucleation and subsequent growth}

\begin{tabular}{ccccc}
11 & $\mathrm{~A}_{1}, \mathrm{~F}_{1}$ & Avrami-Erofeev equation & $-\ln (1-a)$ & $(1-a)$ \\
\hline 12 & $\mathrm{~A}_{3 / 2}$ & Avrami-Erofeev equation & {$[-\ln (1-a)]^{2 / 3}$} & $(3 / 2)(1-a)[-\ln (1-a)]^{1 / 3}$ \\
\hline $\mathbf{1 3}$ & $\mathrm{A}_{2}$ & Avrami-Erofeev equation & {$[-\ln (1-a)]^{1 / 2}$} & $2(1-a)[-\ln (1-a)]^{1 / 2}$ \\
\hline $\mathbf{1 4}$ & $\mathrm{A}_{3}$ & Avrami-Erofeev equation & {$[-\ln (1-a)]^{1 / 3}$} & $3(1-a)[-\ln (1-a)]^{2 / 3}$ \\
\hline $\mathbf{1 5}$ & $\mathrm{A}_{4}$ & Avrami-Erofeev equation & {$[-\ln (1-a)]^{1 / 4}$} & $4(1-a)[-\ln (1-a)]^{3 / 4}$ \\
\hline $\mathbf{1 6}$ & $\mathrm{A}_{u}$ & Prout-Tomkins equation & $\ln [(a /(1-a)]$ & $a(1-a)$
\end{tabular}

Assumed random nucleation and its subsequent growth, $\mathrm{n}=1$

Assumed random nucleation and its subsequent growth, $\mathrm{n}=1.5$

Assumed random nucleation and its subsequent growth, $\mathrm{n}=2$

Assumed random nucleation and its subsequent growth, $\mathrm{n}=2.5$

Assumed random nucleation and its subsequent growth, $\mathrm{n}=3$

Assumed random nucleation and its subsequent growth, $n=4$ Branching nuclei

\section{Deceleratory rate equations}

4.1. Phase boundary reaction

\begin{tabular}{cccccc}
17 & $R_{1}, F_{0}, P_{1}$ & Power law & $a$ & $(1-a)^{0}$ \\
\hline 18 & $R_{2}, F_{1 / 2}$ & Power law & $1-(1-a)^{1 / 2}$ & $2(1-a)^{1 / 2}$ \\
\hline 19 & $R_{3}, F_{2 / 3}$ & Power law & $1-(1-a)^{1 / 3}$ & $3(1-a)^{2 / 3}$
\end{tabular}

4.2. Based on the diffusion mechanism

\begin{tabular}{lllccc}
$\mathbf{2 0}$ & $\mathrm{D}_{1}$ & Parabola low & $a^{2}$ & One-dimensional diffusion \\
\hline $\mathbf{2 1}$ & $\mathrm{D}_{2}$ & Valensi equation & $\begin{array}{c}\mathrm{a}+(1-a) \ln ((1 \\
-a)\end{array}$ & {$[-\ln (1-a)]^{-1}$} & Two-dimension diffusion \\
\hline $\mathbf{2 2}$ & $\mathrm{D}_{3}$ & Jander equation & {$\left[1-(1-a)^{1 / 3}\right]^{2}$} & $(3 / 2)(1-a)^{2 / 3}\left[1-(1-a)^{1 / 3}\right]^{-1}$ & $\begin{array}{c}\text { Three-dimensional diffusion, } \\
\text { spherical symmetry }\end{array}$ \\
\hline $\mathbf{2 3}$ & $\mathrm{D}_{4}$ & Ginstling-Brounstein equation & $1-2 a / 3-(1-a)^{2 / 3}$ & $(3 / 2)\left[(1-a)^{-1 / 3}-1\right]^{-1}$ & $\begin{array}{c}\text { Three-dimensional diffusion, } \\
\text { cylindrical symmetry }\end{array}$ \\
\hline $\mathbf{2 4}$ & $\mathrm{D}_{5}$ & Zhuravlev, Lesokin, Tempelman equation & {$\left[(1-a)^{-1 / 3}-1\right]^{2}$} & $(3 / 2)(1-a)^{4 / 3}\left[(1-a)^{-1 / 3}-1\right]^{-1}$ & Three-dimensional diffusion \\
\hline $\mathbf{2 5}$ & $\mathrm{D}_{6}$ & anti-Jander equation & {$\left[(1+a)^{1 / 3}-1\right]^{2}$} & $(3 / 2)(1+a)^{2 / 3}\left[(1+a)^{1 / 3}-1\right]^{-1}$ & Three-dimensional diffusion \\
\hline $\mathbf{2 6}$ & $\mathrm{D}_{7}$ & anti-Ginstling-Brounstein equation & $1+2 a / 3-(1+a)^{2 / 3}$ & $(3 / 2)\left[(1+a)^{-1 / 3}-1\right]^{-1}$ & Three-dimensional diffusion \\
\hline $\mathbf{2 7}$ & $\mathrm{D}_{8}$ & $\begin{array}{l}\text { anti-Zhuravlev, Lesokin, } \\
\text { Tempelman equation }\end{array}$ & {$\left[(1+a)^{-1 / 3}-1\right]^{2}$} & $(3 / 2)(1+a)^{4 / 3}\left[(1+a)^{-1 / 3}-1\right]^{-1}$ & Three-dimensional diffusion
\end{tabular}

\begin{tabular}{|c|c|c|c|}
\hline 28 & $\mathrm{G}_{1}$ & $1-(1-a)^{2}$ & $1 / 2(1-a)$ \\
\hline 29 & $\mathrm{G}_{2}$ & $1-(1-a)^{3}$ & $1 / 3(1-a)^{2}$ \\
\hline 30 & $\mathrm{G}_{3}$ & $1-(1-a)^{4}$ & $1 / 4(1-a)^{3}$ \\
\hline 31 & $\mathrm{G}_{4}$ & {$[-\ln (1-a)]^{2}$} & $(1 / 2)(1-a)[-\ln (1-a)]^{-1}$ \\
\hline 32 & $\mathrm{G}_{5}$ & {$[-\ln (1-a)]^{3}$} & $(1 / 3)(1-a)[-\ln (1-a)]^{-2}$ \\
\hline 33 & $\mathrm{G}_{6}$ & {$[-\ln (1-a)]^{4}$} & $(1 / 4)(1-a)[-\ln (1-a)]^{-3}$ \\
\hline 34 & $\mathrm{G}_{7}$ & {$\left[1-(1-a)^{1 / 2}\right]^{1 / 2}$} & $4\left\{(1-a)[1-(1-a)]^{1 / 2}\right\}^{1 / 2}$ \\
\hline 35 & $\mathrm{G}_{8}$ & {$\left[1-(1-a)^{1 / 3}\right]^{1 / 2}$} & $6(1-a)^{2 / 3}\left[1-(1-a)^{1 / 3}\right]^{1 / 2}$ \\
\hline
\end{tabular}

Table 3. Algebraic expressions of functions $g(\alpha)$ and $f(\alpha)$ and its corresponding mechanism. [20]

3. táblázat Algebrai kifejezések a $g(\alpha)$ és $f(\alpha)$ függvényekre és a hozzájuk tartozó mechanizmusok. [20] 


\section{Results and discussion}

Thermograms (TGA and DTG) curves of OPC containing polycarboxylate admixtures (dose $=1.0$ or $1.5 \%$ ) and the control sample are shown in Figs. 1 and 2. The curves show three weight loss zones. The first drop in weight ranging from 100 to $200{ }^{\circ} \mathrm{C}$, is accounted for the dehydration of Ca-silicate hydrates. The second weight loss is displayed at 450 to $500{ }^{\circ} \mathrm{C}$ which is attributed to dehydroxyaltion of portlandite. The third loss of weight shown at 700 to $750{ }^{\circ} \mathrm{C}$, is due to decarbonation of calcium carbonate. The thermal analyses data are summarized in Table 3. It shows that the modified OPC Samples decompose at higher temperatures than that found for untreated OPC. This refers to that the addition of polycarboxylate admixture increases the thermal stability of OPC.

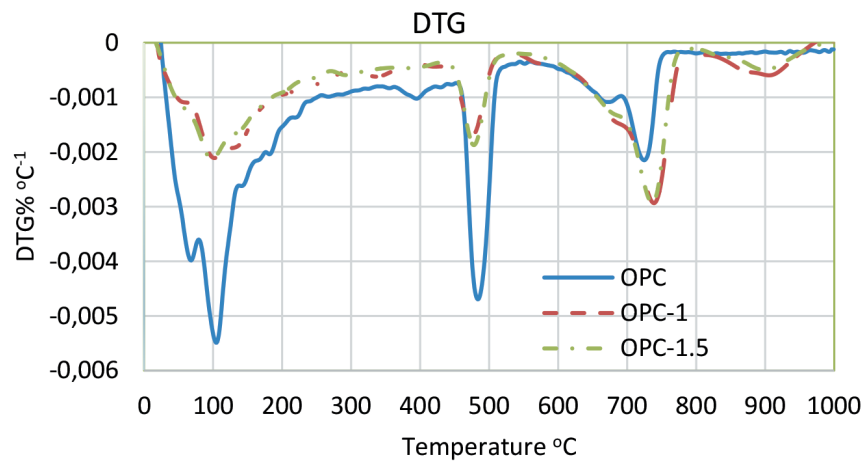

Fig. 1. DTG curves of the thermal decomposition of OPC containing polycarboxylate heating rate $=10 \mathrm{Kmin}^{-1}$

1. ábra DTG görbék polikarboxilát tartalmú cementpépekre, felfütési sebesség $=10 \mathrm{Kmin}^{-1}$

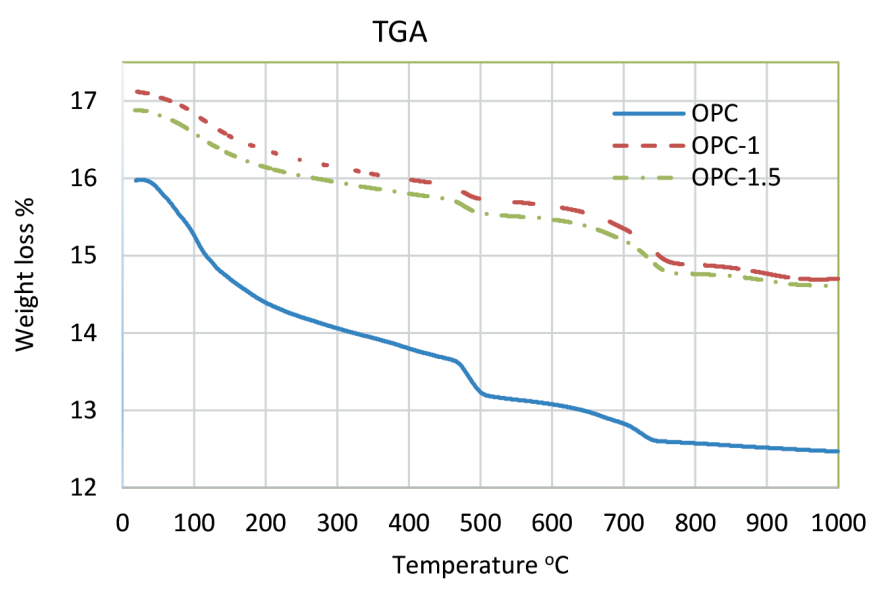

Fig. 2. TGA curves of the thermal decomposition of OPC containing polycarboxylate, heating rate $=10 \mathrm{Kmin}^{-1}$

2. ábra TGA görbék polikarboxilát tartalmú cementpépekre, felfütési sebesség $=10 \mathrm{Kmin}^{-1}$

The kinetic parameters for the three stages of the thermal decomposition of the investigated samples were calculated using fraction conversion $0.1<\alpha<0.8$ obtained from a single thermos-analytical curve (heating rate $10 \mathrm{~K} / \mathrm{min}$ ). In this study, four calculation methods: Coats and Redfern [21] Eq. (7) and Madhysudanan-Krishnan-Ninan [22], Eq. (8), Wanjun et al. [22] Eq. (9) and Tang et al.[23] Eq. (10)as as well as 35 mechanism models $\mathrm{g}(\alpha)$ were used to get the kinetic data:

$$
\begin{aligned}
& \ln \left(\frac{\mathrm{g}(\alpha)}{T^{2}}\right)=\ln \left[\frac{A R}{\beta E_{a}}\left(1-\frac{2 R T}{E_{a}}\right)\right]-\frac{E_{a}}{R T} \cong \ln \left(\frac{A R}{\beta E_{a}}\right)-\frac{E_{a}}{R T} \\
& \ln \left(\frac{\mathrm{g}(\alpha)}{T^{2}}\right)=\ln \left[\frac{A R}{\beta\left(1.00198882 E+1.87391198 R T_{p}\right)}\right]-\frac{E_{a}}{R T} \\
& \ln \left[\frac{g(\alpha)}{T^{1.894661}}\right]=\left[\ln \frac{A E_{a}}{\beta R}+3.635041-1.89466 \ln E_{a}\right]-\frac{1.00145033 E_{a}}{R T} \\
& \ln \left[\frac{\mathrm{g}(\alpha)}{\mathrm{T}^{1.921503}}\right]=\left[\frac{\ln A E_{a}}{\beta R}+3.772050-1.921503 \ln E_{a}\right]-\frac{0.120394 E_{a}}{\mathrm{~T}}
\end{aligned}
$$

Plotting the left-hand sides of Eqs. (7-10), which involves $g(\alpha)$ versus $1 / T$, gives $E_{\mathrm{a}}$ and $A$ from the slope and intercept, respectively. The model that gives the higher correlation coefficient of the linear regression $R^{2}$ for Eqs. (7) - (10) fit is chosen as the selected kinetic model. A mathematical program based on Excel 2016 was designed by the authors to calculate values of activation energy $\mathrm{Ea}$ and the pre-exponential as shown in Table 4.

The best mechanisms for each decomposition step, the kinetic results of the applied equations show kinetic models and parameters close to each other in the most cases as shown in Table 4. From which the best kinetic models according to the highest correlation coefficients and the kinetic parameters are given in Table 5. It can be seen that the mechanism of step depends on the percentage of the superplasticizer.

The pre-exponential factor $A$ is calculated from the intercept of the plots of Eqs. (7-10), and from the theory of the activated complex (transition state) of Eyring [24,25], the following general equation may be written:

$A=\frac{e k_{B} T_{p}}{h} \exp \left(\frac{\Delta S^{\ddagger}}{R}\right)$

Where: $e=2.7183$ is the Neper number; $k_{\mathrm{B}}$ - Boltzmann constant; $h$ - Plank constant, and $T_{\mathrm{p}}$ is the peak temperature of DTG curve.

According to the values of activation energy $\mathrm{E}$ and preexponential factor $\mathrm{A}$ for the different stages of decomposition, The calculated values of $\Delta \mathrm{S}^{*}, \Delta \mathrm{H}^{*}$ and $\Delta \mathrm{G}^{*}$ are calculated using Eqs. $(18-20)$ at $T=T_{\mathrm{p}}\left(T_{\mathrm{p}}\right.$ is the DTG peak temperature at the corresponding stage), because this temperature characterizes the highest rate of the decomposition process. Therefore, the change of the activated entropy can be calculated according to the formula:

$\Delta S^{\neq}=R \ln \frac{A h}{e k_{B} T_{p}}$

Since

$\Delta H^{\neq}=E-R T_{p}$

The changes in the activated enthalpy $\Delta \mathrm{H}^{*}$ and the Gibbs free energy $\Delta G^{*}$ for the activated complex formation from the reactant are calculated using the well-known thermodynamical equation:

$\Delta G^{\neq}=\Delta H^{\neq}-T_{p} \Delta S^{\neq}$ 


\begin{tabular}{|c|c|c|c|c|c|c|}
\hline & & & \multicolumn{4}{|c|}{ Kinetic models } \\
\hline & \multicolumn{2}{|c|}{ Decomposition step } & Eq 7 & Eq 8 & Eq 9 & Eq 10 \\
\hline \multirow[t]{12}{*}{ OPC } & \multirow[t]{4}{*}{$1^{\text {St }}$ step } & Mechanism & $\mathrm{F} 3 / 2$ & $\mathrm{~F} 3 / 2$ & $\mathrm{~F} 3 / 2$ & $\mathrm{~F} 2$ \\
\hline & & $\operatorname{Max}^{2}$ & 0.9969 & 0.9969 & 0.9969 & 0.9941 \\
\hline & & $\mathrm{Ea}$ & 99.764 & 99.764 & 99.910 & 115.2940 \\
\hline & & $A$ & $3.171 \mathrm{E}+13$ & $2.764 \mathrm{E}+14$ & $3.51913 E+13$ & $1.42983 E+16$ \\
\hline & \multirow[t]{4}{*}{$2^{\text {nd }}$ step } & Mechanism & G6 & $\mathrm{P} 1 / 4$ & G6 & G6 \\
\hline & & $\operatorname{Max} \mathrm{R}^{2}$ & 0.9968 & 0.9993 & 0.9968 & 0.9973 \\
\hline & & Ea & 1313.022 & 50.837 & 1317.998 & 1339.6461 \\
\hline & & $A$ & $2.838 \mathrm{E}+90$ & $2.599 \mathrm{E}+03$ & $3.05568 \mathrm{E}+93$ & $7.87165 \mathrm{E}+94$ \\
\hline & \multirow[t]{4}{*}{$3^{\text {rd }}$ step } & Mechanism & $\mathrm{Au}$ & D7 & G6 & G6 \\
\hline & & Max R & 0.9948 & 0.9955 & 0.9912 & 0.9933 \\
\hline & & $\mathrm{Ea}$ & 614.035 & 275.823 & 802.540 & 805.8707 \\
\hline & & $\mathrm{A}$ & $1.107 \mathrm{E}+32$ & $4.103 E+13$ & $2.02021 \mathrm{E}+45$ & $2.40603 \mathrm{E}+45$ \\
\hline \multirow[t]{12}{*}{ OPC+1.0\% } & \multirow[t]{4}{*}{$1^{\text {St }}$ step } & Mechanism & F3/2 & D5 & D5 & D5 \\
\hline & & $\operatorname{Max~R}^{2}$ & 0.9988 & 0.9993 & 0.9993 & 0.9994 \\
\hline & & $\mathrm{Ea}$ & 46.839 & 95.010 & 95.158 & 93.8318 \\
\hline & & $\mathrm{A}$ & $5.750 \mathrm{E}+05$ & $8.550 E+12$ & $1.08953 \mathrm{E}+12$ & $6.51732 \mathrm{E}+11$ \\
\hline & \multirow{4}{*}{$2^{\text {nd }}$ step } & Mechanism & G8 & D7 & D1 & D1 \\
\hline & & $\operatorname{Max}^{2}$ & 0.9906 & 0.9956 & 0.9799 & 0.9688 \\
\hline & & $\mathrm{Ea}$ & -7.889 & 85.079 & 91.518 & 93.8317 \\
\hline & & $\mathrm{A}$ & $-4.440 \mathrm{E}-03$ & $4.412 \mathrm{E}+04$ & 189154.1585 & 281841.940 \\
\hline & \multirow{4}{*}{$3^{\text {rd }}$ step } & Mechanism & $\mathrm{Au}$ & $\mathrm{P} 1 / 4$ & D5 & G6 \\
\hline & & $\operatorname{Max~R}^{2}$ & 0.9941 & 0.9977 & 0.9937 & 0.9920 \\
\hline & & $\mathrm{Ea}$ & 825.910 & 47.965 & 719.201 & 1337.9727 \\
\hline & & A & $8.463 E+42$ & $1.531 \mathrm{E}+02$ & $6.73532 \mathrm{E}+36$ & $9.34991 \mathrm{E}+72$ \\
\hline \multirow[t]{12}{*}{$\mathrm{OPC}+1.5 \%$} & \multirow[t]{4}{*}{$1^{\text {st }}$ step } & Mechanism & G8 & F2 & F2 & F2 \\
\hline & & $\operatorname{Max}^{2}$ & 0.9969 & 0.9965 & 0.9965 & 0.9970 \\
\hline & & $\mathrm{Ea}$ & -3.388 & 60.676 & 60.863 & 61.7420 \\
\hline & & $\mathrm{A}$ & -8.774E- & $9.514 \mathrm{E}+08$ & 122772431.9 & 163422155. \\
\hline & \multirow[t]{4}{*}{$2^{\text {nd }}$ step } & Mechanism & G8 & D7 & G6 & G6 \\
\hline & & Max R ${ }^{2}$ & 0.9845 & 0.9945 & 0.9620 & 0.9598 \\
\hline & & $\mathrm{Ea}$ & -8.314 & 86.000 & 268.665 & 270.7971 \\
\hline & & $\mathrm{A}$ & $-4.269 \mathrm{E}-$ & $3.074 \mathrm{E}+04$ & $2.96196 \mathrm{E}+20$ & $3.21247 \mathrm{E}+20$ \\
\hline & \multirow[t]{4}{*}{$3^{\text {rd }}$ step } & Mechanism & G6 & $\mathrm{P} 1 / 4$ & D5 & D5 \\
\hline & & $\operatorname{Max~R}^{2}$ & 0.9976 & 0.9988 & 0.9982 & 0.9984 \\
\hline & & Ea & 1653.171 & 62.673 & 898.848 & 886.3492 \\
\hline & & $A$ & $9.769 \mathrm{E}+85$ & $1.044 \mathrm{E}+03$ & $6.97492 E+45$ & $1.42405 \mathrm{E}+45$ \\
\hline
\end{tabular}

Table 4. Kinetic parameters, activation energy (Ea) and the pre-exponential (A) calculated from Coats et al. Eq. (7), Wanjun et al. Eq. (8), Madhysudanan et al Eq. (9) and Tang et al. Eq. (10), according to maximum correlation coefficients out of 35 models of mechanism of decomposition of different cement pastes

4. táblázat Kinetikai paraméterek, aktiválási energia (Ea) és hatványkitevő (A) számított értékei Coats et al. Eq. (7), Wanjun et al. Eq. (8), Madhysudanan et al Eq. (9) és Tang et al. Eq. (10) alapján

Decomposition step

\section{Dehydration}

\section{Dihydroxylation}

\section{Decarbonation}

\section{OPC}

$\mathrm{F}_{3 / 2}$ - Chemical reaction

G6 - Unjustified mechanism

G6 - Unjustified mechanism

\section{$\mathrm{OPC}+1.0 \%$}

D5 - Three-dimensional diffusion D1 - One dimensional diffusion

P $1 / 4$ - Nucleation

\section{OPC $+1.5 \%$}

F2 - Second order reaction G6 - Unjustified mechanism P $1 / 4$ - Nucleation

Table 5. Summary of the rate determining mechanism of the thermal decomposition steps of the neat cement pastes and the superplasticized cement pastes with 1.0 and $1.5 \%$ 5. táblázat A höbomlási lépcsők mechanizmusainak összefoglalása tiszta cementpépekre, ill. 1,0 és 1,5\% folyósitószer tartalmú cementpépekre

\begin{tabular}{lccccc} 
Decomposition step & & OPC & OPC+1.0\% & OPC+1.5\% & Units \\
\cline { 2 - 6 } Dehydration & $\Delta \mathrm{S}^{\#}$ & 4.24 & -28.92 & -97.85 & $\mathrm{~J} / \mathrm{mol} . \mathrm{K}$ \\
\cline { 2 - 6 } & $\Delta \mathrm{H}^{\#}$ & 96.80 & 90.72 & 58.63 & $\mathrm{~kJ} / \mathrm{mol}$ \\
\cline { 2 - 6 } Dihydroxylation & $\Delta \mathrm{G}^{\#}$ & 95.22 & 101.51 & 95.13 & $\mathrm{KJ} / \mathrm{mol}$ \\
\hline \multirow{3}{*}{ Decarbonation } & $\Delta \mathrm{S}^{\#}$ & -195.22 & -171.67 & -174.68 & $\mathrm{~J} /(\mathrm{mol} . \mathrm{K})$ \\
\cline { 2 - 6 } & $\Delta \mathrm{H}^{\#}$ & 44.81 & 79.049 & 79.97 & $\mathrm{~kJ} / \mathrm{mol}$ \\
\cline { 2 - 6 } & $\Delta \mathrm{G}^{\#}$ & 185.95 & 203.17 & 206.26 & $\mathrm{KJ} / \mathrm{mol}$ \\
\hline & $\Delta \mathrm{S}^{\#}$ & -2.45 & -221.23 & -205.27 & $\mathrm{~J} /(\mathrm{mol} . \mathrm{K})$ \\
\cline { 2 - 6 } & $\Delta \mathrm{H}^{\#}$ & 267.71 & 39.85 & 54.56 & $\mathrm{~kJ} / \mathrm{mol}$ \\
\cline { 2 - 6 } & $\Delta \mathrm{G}^{\#}$ & 270.10 & 255.11 & 254.28 & $\mathrm{KJ} / \mathrm{mol}$
\end{tabular}

Table 6. Thermodynamic parameters for different stages of thermal decomposition of hardened neat cement past and plasticized cement paste 6. táblázat Termodinamikai paraméterek a hőbomlás különbözö fázisaiban tiszta cementpépekre és folyósitószer tartalmú cementpépekre 
The thermodynamic results obtained are given in Table 6. From which it can be seen that the $\Delta S^{\#}$ value for the first decomposition stage of the hardened cement past is positive. It means that the activated complexes are less order in the arrangement, higher entropy. However, first decomposition stages of plasticized samples with 1.0 and $1.5 \%$ show negative values of $\Delta S^{\#}$ it means that the corresponding activated complex more arrangement lower entropy. While for the $2^{\text {nd }}$ and $3^{\text {rd }}$ decomposition stage, the corresponding activated complexes have negative values of $\Delta \mathrm{S}^{\#}$ referring to higher degree of arrangement, i.e lower entropy than the initial state.

\section{Conclusions}

The addition of polycarboxylate superplasticizer into OPC with 1 and 1.5 wt $\%$ increased its thermal stability without any change in the thermal decomposition products. Whereas, the kinetic study showed that the mechanism for each decomposition step depends on the percentage of plasticizer found in the OPC sample.

\section{Compliance with Ethical Standards}

The authors declare that they have no conflict of interest.

\section{References}

[1] Sha W. - Pereira G.: Differential scanning calorimetry study of ordinary Portland cement paste containing metakaolin and theoretical approach of metakaolin activity. Cem Concr Compos. 2001;23(6):455-461. https://doi.org/10.1016/S0958-9465(00)00090-1

[2] Gruyaert E. - Robeyst N. - De Belie N.: Study of the hydration of Portland cement blended with blast-furnace slag by calorimetry and thermogravimetry. J Therm Anal Calorim. 2010;102(3):941-951. https://doi.org/10.1007/s10973-010-0841-6

[3] Mendes A. - Sanjayan J. - Collins F.: Phase transformations and mechanical strength of OPC/Slag pastes submitted to high temperatures. Mater Struct. 2008;41(2):345-350. https://doi.org/10.1617/s11527-007-9247-8

[4] Zelic J. - Ugrina L. - Jozic D.: Application of Thermal Methods in the Chemistry of Cement: Kinetic of Portlandite from Non-Isothermal Thermogravimetric Data. First Int Profic Test Conf. 2007:420-429.

[5] Sha W. - O'Neill E. A. - Guo Z.: Differential scanning calorimetry study of ordinary Portland cement. Cem Concr Res. 1999;29(9):1487-1489. https://doi.org/10.1016/S0008-8846(99)00128-3

[6] Pane I. - Hansen W.: Investigation of blended cement hydration by isothermal calorimetry and thermal analysis. Cem Concr Res. 2005;35(6):1155-1164. https://doi.org/10.1016/j.cemconres.2004.10.027

[7] Agarwal S. K. - Masood I. - Malhotra SK.: Compatibility of superplasticizers with different cements. Constr Build Mater. 2000;14(5):253-259. https://doi.org/10.1016/S0950-0618(00)00025-8

[8] Ye G. - Liu X. - De Schutter G. - Taerwe L. - Vandevelde P.: Phase distribution and microstructural changes of self-compacting cement paste at elevated temperature. Cem Concr Res. 2007;37(6):978-987. https://doi.org/10.1016/j.cemconres.2007.02.011

[9] Kong D. L. Y. - Sanjayan J. G.: Effect of elevated temperatures on geopolymer paste, mortar and concrete. Cem Concr Res. 2010;40(2):334339. https://doi.org/10.1016/j.cemconres.2009.10.017

[10] Heikal M. - Ali AI - Ismail M. N. - Ibrahim SANS.: Behavior of composite cement pastes containing silica nano-particles at elevated temperature. Constr Build Mater. 2014;70:339-350.

https://doi.org/10.1016/j.conbuildmat.2014.07.078
[11] Musa N. M.: Thermal Analysis of Cement Paste Partially Replaced With Neem Seed Husk Ash. Int J Sci Eng Res. 2014;5(1):1101-1105. http://www.ijser.org.

[12] Klimesch D. S. - Ray A.: The use of DTA/TGA to study the effects of ground quartz with different surface areas in autoclaved cement: quartz pastes. Part 1: A method for evaluating DTA/TGA results. Thermochim Acta. 1996;289(1):41-54. https://doi.org/10.1016/S0040-6031(96)03033-X

[13] Alarcon-Ruiz L. - Platret G. - Massieu E. - Ehrlacher A.: The use of thermal analysis in assessing the effect of temperature on a cement paste. Cem Concr Res. 2005;35(3):609-613.

https://doi.org/10.1016/j.cemconres.2004.06.015

[14] Bhatty J. I. - Reid K. J.: Use of thermal analysis in the hydration studies of a type 1 portland cement produced from mineral tailings. Thermochim Acta. 1985;91:95-105. https://doi.org/10.1016/0040-6031(85)85205-9

[15] F. Paulik - J. Paulik M. A.: Thermal decomposition of gypsum. Thermochim Acta. 1992;200:195-204. https://doi.org/10.1016/0040-6031(92)85115-C

[16] Sha W. - Pereira G. B.: Differential scanning calorimetry study of ordinary Portland cement paste containing metakaolin and theoretical approach of metakaolin activity. Cem Concr Compos. 2001;23(6):455-461. https://doi.org/10.1016/S0958-9465(00)00090-1

[17] Gard J. A. - Taylor H. F. W.: Calcium silicate hydrate (II) (“C-S-H(II)"). Cem Concr Res. 1976;6(5):667-677. https://doi.org/10.1016/0008-8846(76)90031-4

[18] Alarcon-Ruiz L. - Platret G. - Massieu E. - Ehrlacher A.: The use of thermal analysis in assessing the effect of temperature on a cement paste. Cem Concr Res. 2005;35(3):609-613. https://doi.org/10.1016/j.cemconres.2004.06.015

[19] Skibsted J. - Jakobsen H. J. - Hall C.: Quantification of calcium silicate phases in Portland cements by 29 Si MAS NMR spectroscopy. J Chem Soc 1995;91(24):4423-4430.

[20] Vlaev L. - Nedelchev N. - Gyurova K. - Zagorcheva M.: A comparative study of non-isothermal kinetics of decomposition of calcium oxalate monohydrate. J Anal Appl Pyrolysis. 2008;81(2):253-262. https://doi.org/10.1016/j.jaap.2007.12.003

[21] Abbasi M. H. - Kahrizsangi R. E.: Evaluation of reliability of CoatsRedfernnext term method for kinetic analysis of non-isothermal TGA. TransNonfferous Met Soc China. 2008:217-221. https://doi.org/10.1016/S1003-6326(08)60039-4

[22] Georgieva V. - Vlaev L. - Gyurova K.: Non-isothermal degradation kinetics of CaCO3 from different origin. J Chem. 2013;2013. https://doi.org/10.1155/2013/872981

[23] Torkkeli A.: Droplet microfluidics on a planar surface. VTT Publ. 2003;55(504):3-194. https://doi.org/10.1002/aic

[24] Giese B. C. H. - Bamford, C. F. H.: Tipper (Eds.): Comprehensive Chemical Kinetics, Vol. 16, Liquid-Phase Oxidation, Elsevier, Amsterdam 1980. 264 Seiten, Preis: US \$ 87.75. Berichte der Bunsengesellschaft für Phys Chemie. 1981;85(9):721-722. https://doi.org/10.1002/bbpc.19810850935

[25] Dsc C. F. - Dielectric B.: Journal of Thermal Analysis and Calorimetry. Vol 91. Kluwer Academic Publishers; 2008.

https://doi.org/10.1007/s10973-008-3100-3

$\underline{\text { Ref.: }}$

Gad, Elshafie A. M. - Habib, Amr Osman - Mousa, Mahmoud M.: Understanding the Mechanism of Decomposition Reactions of Neat and Superplasticized ordinary Portland Cement Pastes Using Thermal Analysis

Építőanyag - Journal of Silicate Based and Composite Materials, Vol. 69, No. 3 (2017), 102-107. p. https://doi.org/10.14382/epitoanyag-jsbcm.2017.18 